World Journal of Chemistry 3 (2): 55-60, 2008

ISSN $1817-3128$

(C) IDOSI Publications, 2008

\title{
A Systematic Study on Extraction of Lipase Obtained by Solid State Fermentation of Soybean Meal by a Newly Isolated Strain of Penicillium sp
}

\author{
${ }^{1}$ Renata Vardanega, ${ }^{1}$ Daniela Remonatto, ${ }^{1}$ Francieli Arbter, ${ }^{1}$ André Polloni, ${ }^{2}$ Elisandra Rigo, \\ ${ }^{2}$ Jorge Luiz Ninow, ${ }^{\prime}$ Helen Treichel, ${ }^{\prime}$ Débora de Oliveira and ${ }^{I}$ Marco Di Luccio
}

Programa de Mestrado em Engenharia de Alimentos, Universidade Regional Integrada do Alto Uruguai e das Missões - Campus de Erechim, Av. Sete de Setembro, 1621, 99700-000, Erechim, RS, Brasil

\begin{abstract}
This work aimed to assess the effect of some variables on the lipase extraction from the fermented medium in order to establish the experimental conditions that maximize the yield of the enzyme obtained from solid state fermentation of soybean meal and a newly isolated strain of Penicillium sp. The experimental design technique was used to investigate the effect of relevant variables on lipase activity. The factors investigated were solvent $\mathrm{pH}(5.5-8.5)$, stirring rate $(50-150 \mathrm{rpm})$, temperature $\left(25-49^{\circ} \mathrm{C}\right)$ and solid:liquid ratio $(1: 20-5: 20)$. The effect of time of contact was evaluated in a kinetic study. Higher lipase activities in the extraction study were obtained using phosphate buffer $100 \mathrm{mM} \mathrm{pH} 7.0$, at $25^{\circ} \mathrm{C}, 150 \mathrm{rpm}$ and solid:liquid ratio of 5:20. Extraction kinetics showed that maximum activity $(175.15 \mathrm{U} / \mathrm{g})$ was obtained in $15 \mathrm{~min}$ of extraction.
\end{abstract}

$\underline{\text { Key words: Experimental design } \cdot \text { Sxtraction } \cdot \text { Kinetics } \cdot \text { Lipase } \cdot \text { Optimization } \cdot \text { Solid state fermentation }}$

\section{INTRODUCTION}

Lipases (E.C.3.1.1.3) are enzymes that hydrolyze water-insoluble esters, such as long chain triacylglycerols. This class of enzymes acts on the oil-water interface, where the activity of it is increased by interfacial activation. Besides, lipases also catalyze esterification and transesterification reactions when used in non-aqueous medium [1].

Microbial lipases present a large potential of applications, involving food, pharmaceutical, chemistry, waste treatment, tannery, cosmetics and medical industry [1-3]. Many techniques for obtaining high yields in lipase production have been developed and improved. More resistant and specific enzymes have been sought for increasing the possible industrial applications of these catalysts [4].

Recently, lipases have achieved a prominent position on the world enzyme market, clearly demonstrated by the large amount of information reported in the literature [5]. After the proteases and amylases, lipases are considered as the third group in sales volume, involving a one billion dollar trade and showing great versatility, which makes them especially attractive for industrial applications [5-7]. Though considerable progress has been made over recent years towards developing cost-effective systems using enzymes as catalysts, at present, the high cost of enzyme production still remains the major obstacle to large-scale industrial applications of enzyme-catalyzed processes [6]. The lipases production by solid state fermentation (SSF) on different substrates combined to the large variety of fungi available has already been reported in many studies, as well as the advantages of this fermentation technique when compared to the submerged fermentation [8,9]. In this sense, it is important to mention that the use of agroindustrial residues as substrates in the production of lipase by solid-state fermentation could significantly reduce the final price of the enzyme and also add value to low cost materials on the market [10]. Besides this, the products obtained by SSF are naturally concentrated at the end of the process, needing to be efficiently extracted from the fermented medium [11].

Temperature and $\mathrm{pH}$ are known to be important parameters in the extraction of solutes from solids. In addition, when dealing with enzymes, the thermal stability of the enzyme, which is a function of the exposure time, must also be taken into account. Therefore when studying the solid-liquid extraction of enzymes, it is of crucial importance to test the influence of five different parameters-type of solvent, solid:liquid ratio, temperature, agitation and contact time - and the interrelation amongst them [12].

Corresponding Author: Helen Treichel, Departamento de Engenharia Química e de Alimentos, Universidade Federal de Santa Catarina, UFSC, SC, Brasil 
Few studies on enzyme extraction in SSF have been reported in literature. Some reports investigated the extraction of pectinases obtained by SSF, verifying the influence of temperature, stirring rate and time of extraction in batch extraction and in fixed bed multiple stage extraction [12]. The extraction of xylanases obtained by SSF was also studied using experimental design technique, where the kind of solvent, the extraction temperature, the solid:liquid ratio, the stirring rate and the extraction time were investigated [13].

In this context, the aim of this work was to assess the extraction parameters of a lipase obtained by a newly isolated strain of Penicillium sp. through solid state fermentation (SSF) using soybean meal as substrate.

\section{MATERIALS AND METHODS}

Microorganism and Inoculum: Following a standard procedure for isolation, several microorganisms were isolated from different sources as olive oil, cheese, tomato extract, soybean oil, milk cream, meat, soybean meal and contaminated culture media (data not shown). The most promising strain, isolated from soybean meal, was preliminarily identified as Penicillium sp. and used in this work. This microorganism was maintained in glycerol and potato dextrose agar slants under refrigeration.

Erlenmeyer flasks $(500 \mathrm{~mL})$ with $100 \mathrm{~mL}$ of sterile PDA (potato dextrose agar) medium were inoculated with $0.5 \mathrm{~mL}$ of a spore suspension obtained from stock cultures. The flasks were incubated for seven days at $30^{\circ} \mathrm{C}$. Spore collection was carried out by adding $20 \mathrm{~mL}$ of an aqueous $0.1 \%(\mathrm{v} / \mathrm{v})$ of Tween 80 solution and sterile glass beads to the flasks. The resulting suspension was then used as inoculum, after adjusting the amount of spores to achieve a final concentration of $10^{8} \mathrm{spores} / \mathrm{g}$ of dry meal [7].

Solid State Fermentation: The substrate used in all runs was soybean meal from a same batch and purchased from a local industry (Olfar, Erechim, Brazil). The meal is the residue of soybean oil extraction after cold press and solvent extraction. The substrate was pre-characterized as $(\mathrm{g} / \mathrm{kg})$ : moisture 30.0 , protein 425.0 , lipids 85.0 , carbohydrate 300.0 , fiber 100.0 , ashes 60.0 , nitrogen 68.0 , carbon 454.0 [14].

The meal was sieved (Tyler 1-115) and the higher fraction (Tyler 9-16) was collected and stored at $-18^{\circ} \mathrm{C}$ until the use. Fermentations were carried out with $10 \mathrm{~g}$ of dry meal in cylindrical reactors covered with hydrophobic fabric. The moisture content of the meal was adjusted to
$55 \%$ with distilled water. After sterilization $\left(121^{\circ} \mathrm{C}, 15 \mathrm{~min}\right)$ each reactor was inoculated with a suspension of spores to a final count of $2 \times 10^{6}$ spores $/ \mathrm{mL}$ and incubated at $27^{\circ} \mathrm{C}$ for $48 \mathrm{~h}$ in a chamber with control of temperature and humidity (set at $85 \%$ of saturation). All experimental conditions were established in previous works [14-16].

Hydrolysis Activity Assay: Lipase hydrolysis activity was assayed using an emulsion of olive oil $(10 \% \mathrm{~m} / \mathrm{v})$ in arabic $\operatorname{gum}(5 \% \mathrm{~m} / \mathrm{v})$ in sodium phosphate buffer $0.1 \mathrm{~mol} / \mathrm{L} \mathrm{pH}$ 7.0. After incubation for 15 minutes at $37^{\circ} \mathrm{C}$ and $160 \mathrm{rpm}$, the reaction was stopped by addition of a solution of acetone/ethanol $(1: 1)$. The fatty acids produced due to the hydrolysis were titrated with $\mathrm{NaOH} 0.05 \mathrm{~mol} / \mathrm{L}$. Control assays (blanks) were carried out adding the acetone/ethanol solution right after the enzyme addition. One unit of lipase activity was defined as the amount of enzyme preparation necessary to produce $1 \mu \mathrm{mol}$ of acid per minute in the assay conditions. The results are expressed in terms of units per gram of dry substrate $(\mathrm{U} / \mathrm{g})[7]$.

Optimization of Extraction Conditions: A factorial experimental design using response surfaces was used to study the enzyme extraction from the fermented medium. A complete factorial design $\left(2^{4}\right)$ was built with this purpose and is presented in Table 1. The factors

Table 1: Matrix of the $2^{4}$ experimental design (coded and real values), with the respective responses in terms of hydrolytic activity (after 30 minutes of extraction)

\begin{tabular}{lccccc}
\hline & $\mathrm{T}$ & Stirring rate & & $\begin{array}{c}\text { Solid:liquid } \\
\text { ratio (S:L) }\end{array}$ & $\begin{array}{c}\text { Hydrolytic } \\
\text { activity }(\mathrm{U} / \mathrm{g})\end{array}$ \\
\hline 1 & $-1(25)$ & $-1(50)$ & $-1(5.5)$ & $-1(5: 20)$ & $85.39 \pm 2.35$ \\
2 & $1(49)$ & $-1(50)$ & $-1(5.5)$ & $-1(5: 20)$ & $39.02 \pm 2.16$ \\
3 & $-1(25)$ & $1(150)$ & $-1(5.5)$ & $-1(5: 20)$ & $107.81 \pm 0.12$ \\
4 & $1(49)$ & $1(150)$ & $-1(5.5)$ & $-1(5: 20)$ & $21.12 \pm 1.69$ \\
5 & $-1(25)$ & $-1(50)$ & $1(8.5)$ & $-1(5: 20)$ & $99.90 \pm 2.74$ \\
6 & $1(49)$ & $-1(50)$ & $1(8.5)$ & $-1(5: 20)$ & $0.99 \pm 1.41$ \\
7 & $-1(25)$ & $1(150)$ & $1(8.5)$ & $-1(5: 20)$ & $114.52 \pm 12.71$ \\
8 & $1(49)$ & $1(150)$ & $1(8.5)$ & $-1(5: 20)$ & 0 \\
9 & $-1(25)$ & $-1(50)$ & $-1(5.5)$ & $1(1: 20)$ & $83.64 \pm 10.05$ \\
10 & $1(49)$ & $-1(50)$ & $-1(5.5)$ & $1(1: 20)$ & $68.40 \pm 8.48$ \\
11 & $-1(25)$ & $1(150)$ & $-1(5.5)$ & $1(1: 20)$ & $21.43 \pm 13.91$ \\
12 & $1(49)$ & $1(150)$ & $-1(5.5)$ & $1(1: 20)$ & $47.40 \pm 4.24$ \\
13 & $-1(25)$ & $-1(50)$ & $1(8.5)$ & $1(1: 20)$ & $153.69 \pm 15.34$ \\
14 & $1(49)$ & $-1(50)$ & $1(8.5)$ & $1(1: 20)$ & 0 \\
15 & $-1(25)$ & $1(150)$ & $1(8.5)$ & $1(1: 20)$ & $186.36 \pm 25.43$ \\
16 & $1(49)$ & $1(150)$ & $1(8.5)$ & $1(1: 20)$ & $1.26 \pm 1.78$ \\
17 & $0(37)$ & $0(100)$ & $0(7.0)$ & $0(3: 20)$ & $96.69 \pm 1.53$ \\
18 & $0(37)$ & $0(100)$ & $0(7.0)$ & $0(3: 20)$ & $79.56 \pm 0.31$ \\
19 & $0(37)$ & $0(100)$ & $0(7.0)$ & $0(3: 20)$ & $91.63 \pm 2.61$ \\
\hline
\end{tabular}

Where: -1 corresponds to the lower level; +1 corresponds to the higher level and 0 to the central point 
investigated were solvent $\mathrm{pH}$ (5.5-8.5), stirring rate (50-150 rpm), temperature $\left(25-49^{\circ} \mathrm{C}\right)$ and solid:liquid ratio (1:20-5:20). The effect of time of contact was evaluated in a kinetic study. The dependent (response) variable was the lipase hydrolytic activity in the crude extract. The solvent (sodium phosphate buffer) and ranges of stirring rate, $\mathrm{pH}$ and temperature were chosen based on some recent studies related to the extraction of xylanases [13], pectinases [12] and inulinases [17] and on our previous experience with lipases [14-16]. It is worth noting that no previous systematic study about lipase extraction could be found in the literature.

Extraction was carried out in erlenmeyer flasks $(250 \mathrm{~mL})$ by addition of the sodium phosphate buffer in the experimental conditions established in the experimental design. The samples ( $10 \mathrm{~g})$ were stirred in an orbital shaker for 30 minutes, condition determined in previous works [14-16]. The separation of the liquid phase was carried out with a manual squeezing device. The supernatant was used to assay lipase activity. All assays were carried out in triplicate runs.

Statistical Analysis: Statistical analysis was performed with the results obtained at $30 \mathrm{~min}$ of extraction using Statistica (StatSoft Inc., version 5.1). The statistical significance of the regression coefficients was $95 \%$. The optimum levels of the variables were obtained by graphical analysis.

\section{RESULTS AND DISCUSSION}

Optimization of Lipase Extraction Conditions: A full experimental design with four variables $(\mathrm{pH}$, temperature, stirring rate and solid:liquid ratio) was carried out so as to verify the first and second order effects and the interaction between the variables during the lipase extraction. Table 1 presents the matrix of the experimental design showing the real and coded values and the respective responses in terms of lipase activity obtained after 30 minutes of extraction, defined in agreement with previous works $[15,16]$. A first view of this table permit us to observe that the highest lipase activity (run 15) was obtained at $25^{\circ} \mathrm{C}, 150 \mathrm{rpm}, \mathrm{pH}$ of 8.5 and solid:liquid ratio of 1:20. On the other hand, it is also observed from this table that the extracts obtained at $37^{\circ} \mathrm{C}$ and $49^{\circ} \mathrm{C}$ presented lower lipase activities.

The results on Table 1 were statistically analyzed, yielding a coded empiric model (Equation 1) for lipase activity as a function of studied factors. The model was validated by analysis of variance (ANOVA, $\mathrm{p}<0.05$,
$\mathrm{R}=0.89$ ) that showed that the calculated $\mathrm{F}$ (19.89) was higher than the tabulated one (3.29). The coded model was used to build the response surfaces showed in Figures 1 and 2.

$$
\mathrm{A}=68.36-42.16 * \mathrm{~T}-26.87 * \mathrm{~T} * \mathrm{pH}+9.89 * \mathrm{pH} * \mathrm{~S}: \mathrm{L}
$$

where:

$\mathrm{A}=$ Lipase activity $(\mathrm{U} / \mathrm{g}$ dry cake);

$\mathrm{T}=$ Temperature $\left({ }^{\circ} \mathrm{C}\right)$;

$\mathrm{pH}=\mathrm{pH}$;

$\mathrm{S}: \mathrm{L}=$ solid:liquid ratio.

As evidenced by Equation 1, the temperature had a negative effect on enzyme extraction from fermented soybean meal. Possibly thermal deactivation of the enzyme might be occurring during extraction. The stability of the crude enzymatic extracts obtained in this work by SSF with Penicillium sp. and soybean meal as substrate showed that temperature of $25^{\circ} \mathrm{C}$ provided the best stability and $\mathrm{pH}$ presented the same rate of activity loss in the whole range investigated (4.9 to 8.5). The effect of $\mathrm{pH}$ was not significant $(\mathrm{p}<0.05)$. However, interaction effects of $\mathrm{pH}$ with the other two variables are pronounced. This study indicates that $\mathrm{pH}$ is a relevant factor for extraction and preservation of enzyme activity.

The extraction of lipases from Penicillium restrictum using babassu cake as substrate was carried out by adding $50 \mathrm{mM}$ phosphate buffer ( $\mathrm{pH} \mathrm{7.0)}$ ) for $30 \mathrm{~min}$ at $37^{\circ} \mathrm{C}$, leading to lipase activities of $30 \mathrm{U} / \mathrm{g}[18,19]$. Cavalcanti et al, adding $100 \mathrm{mM}$ phosphate buffer (pH 7.0) for $20 \mathrm{~min}$ at $35^{\circ} \mathrm{C}$ for lipase extraction from Penicillium simplicissimum using babassu cake as substrate in fixed-bed bioreactors, obtained lipase activities of $26 \mathrm{U} / \mathrm{g}$, equivalent to lipase production in packed-bed bioreactor on the same conditions [20]. Using soybean meal as substrate and Penicillium simplicissimum as microorganism, lipase activities of 30 $\mathrm{U} / \mathrm{g}$ were achieved by adding $100 \mathrm{mM}$ phosphate buffer (pH 7.0) for $30 \mathrm{~min}$ at $35^{\circ} \mathrm{C}$ and $21 \mathrm{U} / \mathrm{g}$ of dry cake was obtained by Di Luccio et al., on the same extraction conditions [15]. Using soybean meal as substrate and extraction conditions described above, Di Luccio et al. obtained maximum values of lipase activity of $40 \mathrm{U} / \mathrm{g}$ of dry meal using Penicillium simplicissimum as microorganism [15].

It is worth mentioning that all works presented in the literature refer to the extraction conditions obtained in non-systematic studies, making relevant the methodology and the results presented here. Usually the method for 


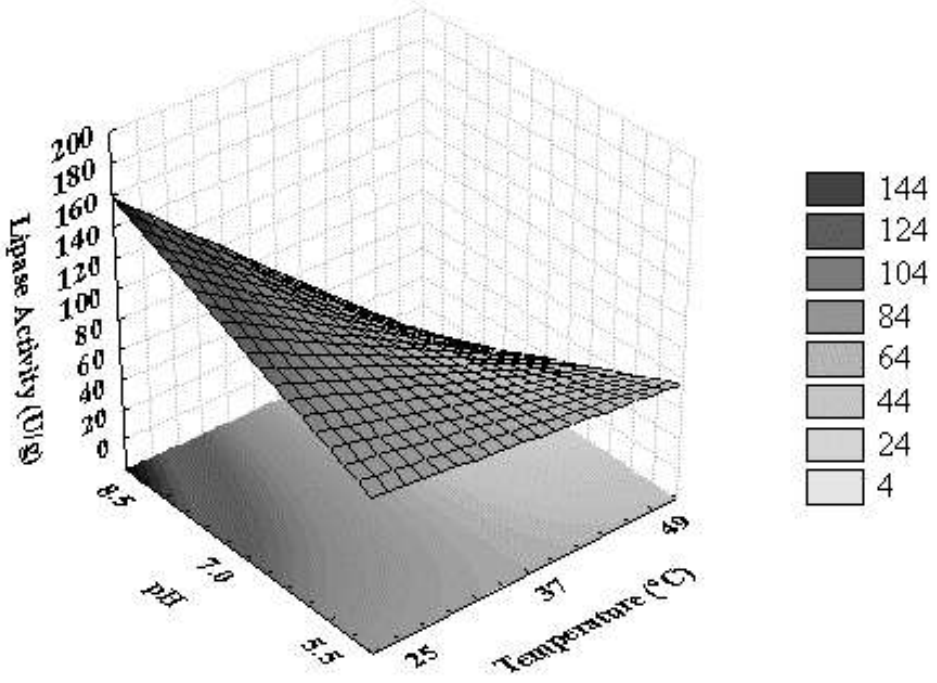

Fig. 1: Response surface for hydrolytic activity as a function of temperature and $\mathrm{pH}$

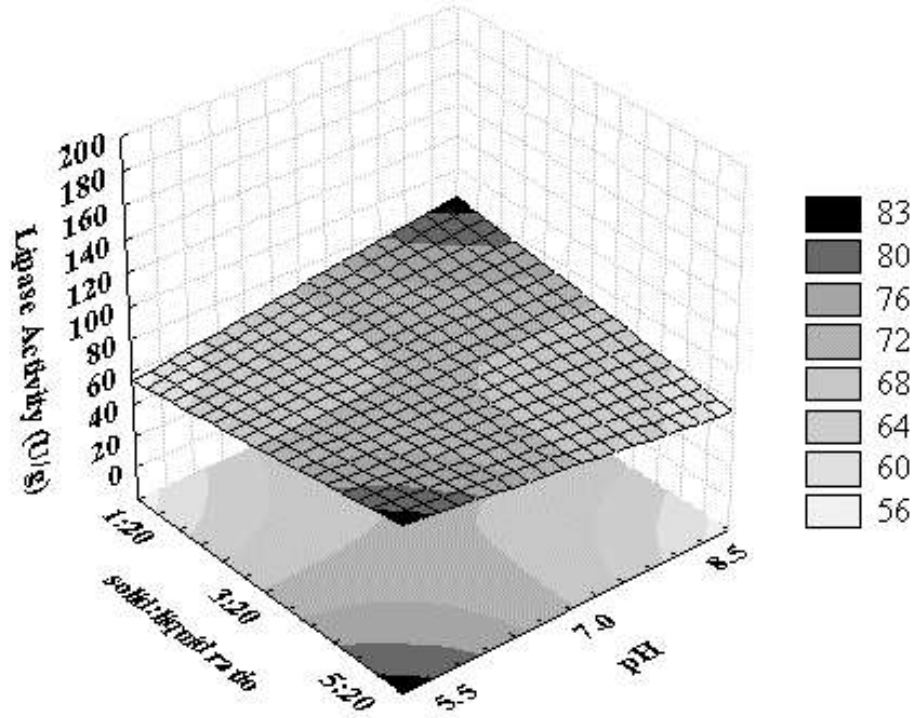

Fig. 2: Response surface for hydrolytic activity as a function of $\mathrm{pH}$ and solid:liquid ratio

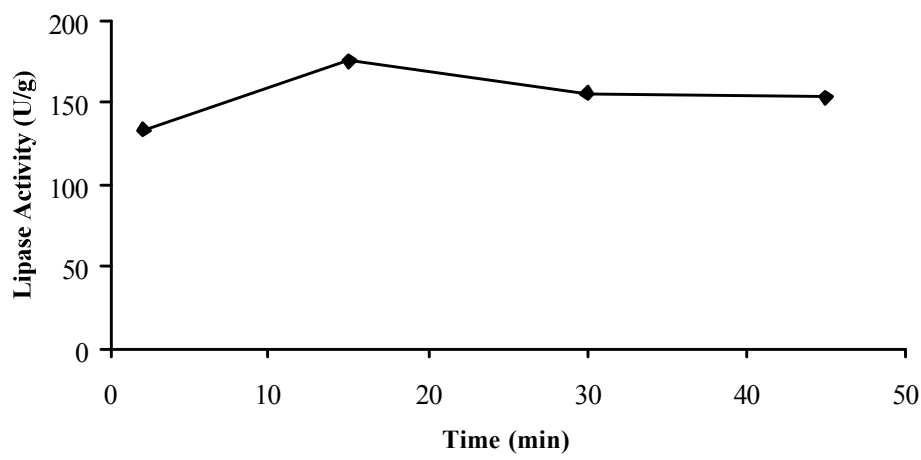

Fig. 3: Kinetics of extraction of lipases from the fermented soybean meal using sodium phosphate buffer $100 \mathrm{mM}$, $\mathrm{pH} 7.0$, at $25^{\circ} \mathrm{C}, 150 \mathrm{rpm}$ in a solid:liquid ratio of 5:20 
determining optimal conditions in bioprocesses is varying one parameter while keeping others at a constant level. This is a time and cost ineffective method that presents also the disadvantage of not including the interaction effects among variables. Optimization using factorial design and response surface methodology can overcome such drawbacks. Factorial design technique has been successfully used to optimize and evaluate effect of process parameters in the production of enzymes and other metabolites [21].

From the results obtained in this work, one can conclude that the study related to the extraction of lipases extraction produced by Penicillium sp. and soybean meal was efficient, leading to maximum values of activity of $186 \mathrm{U} / \mathrm{g}$. Other hypotheses for differences in the enzyme activities obtained in above cited works may be caused by the characteristics of the SSF and the diffusion of nutrients and form on the solid matrix [22]. The presence of different additives in lipase production can have an important impact on the production of different lipases [22,23], depending on the culture conditions and differences in enzyme activity profiles, fact already observed in production of esterase by SSF and submerged (SmF) fermentation [24].

The kinetic study (Figure 3) was carried out at experimental conditions established on the statistical analysis of the experimental design. Temperature was set to the lower level of the design $\left(25^{\circ} \mathrm{C}\right)$, since this factor influenced negatively the lipase extraction. The stirring rate has not influenced the extraction process and was then set at $150 \mathrm{rpm}$, to keep the solids suspended in the liquid $[14,15]$. The $\mathrm{pH}$ was set at the condition of the central point (7.0), since the enzyme was more stable at neutral conditions. Solid:liquid ratio showed no significant influence on lipase extraction. However, when the ratio 5:20 was used, a higher volumetric activity was obtained, facilitating the downstream processing steps.

Figure 3 shows that the extraction of the enzyme occurs basically in the first minutes of the process. Some studies show that the formation of an aerial mycelium is directly related to the enzyme formation rates [25]. Still, small particles of the substrate result in a higher surface area for microorganism growth [1]. As the mycelium development occurs preferentially on the surface, the enzyme might also be concentrated in the surface of the particles, making the extraction easier.

\section{CONCLUSION}

This work evaluated the effect of temperature, stirring rate, $\mathrm{pH}$ and solid:liquid ratio on lipase extraction from fermented soybean meal. After studying the effect of these variables, the extraction procedure was optimized, resulting in activity values of $175 \mathrm{U} / \mathrm{g}$ dry soybean meal, when using sodium phosphate buffer $100 \mathrm{mM} \mathrm{pH} \mathrm{7.0,} \mathrm{at}$ $25^{\circ} \mathrm{C}$ and $150 \mathrm{rpm}$ in a solid:liquid ratio of 5:20 in 15 minutes.

\section{ACKNOWLEDGMENTS}

The authors thank CAPES and CNPq for the financial support of this work and scholarships.

\section{REFERENCES}

1. Pandey, A., S. Benjamin, C.R. Soccol, P. Nigam, N. Kriger and V.T. Soccol, 1999. The realm of microbial lipases in biotechnology. Biotechnol. Appl. Biochem., 29: 119-131.

2. Sharma, R., Y. Chisti and U.C. Banerjee, 2001. Production, purification, characterization and applications of lipases. Biotechnol. Advances, 19: 627-662.

3. Jaeger, K.E. and M.T. Reetz, 1998. Microbial lipases form versatile tools for biotechnology. Trends in Biotechnol., 16: 396-405.

4. Soccol, C.R. and L.P.S. Vandenberghe, 2003. Overview of applied solid state fermentation in Brazil. Biochem. Eng. J., 13: 205-218.

5. Pandey, A., 2003. Solid state fermentation. Biochem. Eng. J., 13: 81-85.

6. Mahadik, N.D., U.S. Puntambekar, K.B. Bastawde, J.M. Khire and D.V. Gokhale, 2002. Production of acidic lipase by Aspergillus niger in solid state fermentation. Process Biochem., 38: 715-721.

7. Freire, D.M.G., E.M.F. Teles, E.P.S. Bon and J.R.G.L. Sant'anna, 1997. Lipase production by Penicillium restrictum in a laboratory scale fermentor: media composition, agitation and aeration. Appl. Biochem. Biotechnol., 63: 409-421.

8. Castilho, L.R., C.M.S. Polato, E.A. Buarque, J.R. Sant'anna and D.M.G. Freire, 2000. Economic analysis of lipase production by Penicillium restrictum in solid state and submerged fermentations. Biochem. Eng. J., 4: 239-247. 
9. Holker, U., M. Hofer and J. Lenz, 2004. Biotechnological advantages of laboratory-scale solid-state fermentation with fungi (Mini review). Appl. Microbiol. Biotechnol., 64: 175-186.

10. Pandey, A. and C.R. Soccol, 2001. Solid state fermentation in biotechnology: fundamentals and applications. Asiatec Publishers.

11. Castilho, L.R., R.A. Medronho and T.L.M. Alves, 2000. Production and extraction of pectinases obtained by solid state fermentation of agroindustrial residues with Aspergillus niger. Bioresource Technol., 71: 45-50.

12. Castilho, L.R., T.L.M. Alves and R.A. Medronho, 1999. Recovery of pectolytic enzymes produced by solid state culture of Aspergillus niger. Process Biochem., 34: 181-186.

13. Heck, J.X., P.F. Hertz and M.A.Z. Ayub, 2005. Extraction optimization of xylanases obtained by solid-state cultivation of Bacillus circulans BL53. Process Biochem., 40: 2891-2895.

14. Vargas, G.D.L.P., H. Treichel, D. Oliveira, S.C. Beneti, D.M.G. Freire and M. Di Luccio, 2008. Optimization of lipase production by Penicillium simplicissimum in soybean meal. J. Chemical Technol. Biotechnol, 83: 47-54.

15. Di Luccio, M., F. Capra, N.P. Ribeiro, G.D.L.P. Vargas, D.M.G. Freire and D. Oliveira, 2004. Effect of temperature, moisture and carbon supplementation on lipase production by solid-state fermentation of soy cake by Penicillium simplicissimum. Appl. Biochem. Biotechnol., 113-116: 173-180.

16. Kempka, A.P., N.L. Lipke, T.L.F. Pinheiro, S. Menoncin, H. Treichel, D.M.G. Freire and M. Di Luccio, 2008. Response surface method to optimize the production and characterization of lipase from Penicillium verrucosum in solid state fermentation. Bioprocess and Biosys. Eng., 31: 119-125.

17. Mazutti, M.A., J.P. Bender, H. Treichel and M. Di Luccio, 2006. Optimization of inulinase production by solid state fermentation using sugarcane bagasse as substrate. Enzyme and Microbial. Technol., 39: 56-59.
18. Gombert, A.K., A.L. Pinto, L.R. Castilho and D.M.G. Freire, 2000. Lipase production by Penicillium restrictum in solid state fermentation using babassu oil cake as substrate. Process Biochem., 35: 85-90.

19. Palma, M.B., A.L. Pinto, A.K. Gombert, K.H. Seitz, S.C. Kivatinitz, L.R. Castilho and D.M.G. Freire, 2000. Lipase production by Penicillium restrictum using solid waste of industrial babassu oil production as substrate. Appl. Biochem. Biotechnol., 84: 1137-1145.

20. Cavalcanti, E.C., M.L.E. Gutarra, D.M.G. Freire, L.R. Castilho and G.L.S. Júnior, 2005. Lipase production by solid state fermentation in fixed bed bioreactors. Brazilian Archives Biology and Technol., 48: 79-84.

21. Montgomery, D.C., 1991. Montgomery: Design and Analysis of Experiments. John Wiley and Sons.

22. Azeredo, L.A.I., P.M. Gomes, J.R. Sant’anna, L.R. Castilho and D.M.G. Freire, 2007. Production and regulation of lipase activity Penicillium restrictum in submerged and solid state fermentation. Currents in Microbiol., 54: 361-365.

23. Mateos Diaz, J.C., J.A. Rodríguez, S. Roussos, J. Cordova, A. Abousalham, F. Carriere and J. Baratti, 2006. Lipase from thermotolerant fungus Rhizopus homothallicus is more thermoestable when produced using solid state fermentation than liquid fermentation procedures. Enzyme and Microbial.. Technol., 39: 1042-1050.

24. Asther, M., M. Haon, S. Roussos, E. Record, M. Delatte, L. Lesage-Meessen and M. Labat, 2002. Feruloyl esterase from Aspergillus niger: a comparison of the production in solid state and submerged fermentation. Process Biochem., 38: 685-691.

25. Sun, S.Y. and Y. Xu, 2008. Solid state fermentation for "whole-cell synthetic lipase" production from Rhizopus chinensis and identification of the functional enzyme. Process Biochem., 43: 219-224. 